\title{
Mortality and Clinical Characteristics of
} Multisystem Inflammatory Syndrome in Children (MIS-C) associated with COVID-19 in critically ill patients: an observational multicenter study (MISCO STUDY)

\section{Lorena Acevedo}

University of La Sabana

Byron Enrique Piñeres-Olave

Clinica Cardiovid

\section{Laura Fernanda Niño-Serna}

Hospital Pablo Tobon Uribe

Liliana Mazillo-Vega

Hospital Infantil Los Angeles

Ivan Jose Ardila Gómez

Clinica Uros

Shayl Chacón

Hospital Universitario San Ignacio

Juan Camilo Jaramillo-Bustamante

Hospital General de Medellin

Hernando Mulett-Hoyos

Fundación Cardioinfantil-Instituto de Cardiologia

Otto Mauricio González-Pardo

Fundacion Clinica Shaio

\section{Eliana Zemanate}

Hospital Susana Lopez de Valencia

Ledys Izquierdo

Hospital Militar Central

Jaime Piracoca Mejía

Clinica Infantil Colsubsidio

Jose Luis Junco González

Instituto Roosvelt

\section{Beatriz Giraldo Durán}

Hospital Infantil de la Cruz Roja 


\section{Carolina Bonilla}

Fundación Santa Fe de Bogotá

\section{Helen Preciado}

Fundación Universitaria de Ciencias de la Salud. Hospital de San José.

\section{Rafael Orozco Marín}

Clinica Portoazul

\section{Martha Alvarez}

Fundación Cardioinfantil-Instituto de Cardiologia

\section{Carolina Giraldo}

Hospital Pablo Tobon Uribe

\section{Jorge Rojas}

Hospital Santa Clara Colombia

\section{Juan Carlos Salazar-Uribe}

National University of Colombia

\section{Juan-Manuel Anaya}

Del Rosario University

Jaime Fernández-Sarmiento ( $\sim$ jaimefe@unisabana.edu.co)

Fundación Cardioinfantil-Instituto de Cardiologia

\section{Research Article}

Keywords: sepsis, SARS-CoV2, PIMS-TS, inflammatory, mortality.

Posted Date: April 13th, 2021

DOl: https://doi.org/10.21203/rs.3.rs-388266/v1

License: (c) (1) This work is licensed under a Creative Commons Attribution 4.0 International License. Read Full License

Version of Record: A version of this preprint was published at BMC Pediatrics on November 18th, 2021. See the published version at https://doi.org/10.1186/s12887-021-02974-9. 


\section{MORTALITY AND CLINICAL CHARACTERISTICS OF MULTISYSTEM INFLAMMATORY SYNDROME IN CHILDREN (MIS-C) ASSOCIATED WITH COVID-19 IN CRITICALLY ILL PATIENTS: AN OBSERVATIONAL MULTICENTER STUDY (MISCO STUDY)}

Lorena Acevedo $\mathrm{MD}^{1}$, Byron Enrique Piñeres-Olave $\mathrm{MD}^{2}$, Laura Fernanda Niño-Serna MD, $\mathrm{MSc}^{3}$, Liliana Mazzillo Vega MD , Ivan Jose Ardila Gomez MD , Shayl Chacón MD ${ }^{6}$, Juan Camilo Jaramillo-Bustamante $\mathrm{MD}^{7}$, Hernando Mulett-Hoyos $\mathrm{MD}^{8}$, González-Pardo OM $\mathrm{MD}^{9}$, Eliana Zemanate $\mathrm{MD}^{10}$, Ledys Izquierdo $\mathrm{MD}^{11}$, Jaime Piracoca Mejìa $\mathrm{MD}^{12}$, Jose Luis Junco González $\mathrm{MD}^{13}$, Beatriz Giraldo Duran MD ${ }^{14}$, Carolina Bonilla Gonzalez $\mathrm{MD}^{15}$, Helen Preciado MD ${ }^{16}$, Rafael Orozco Marun $\mathrm{MD}^{17}$, Martha Alvarez $\mathrm{MD}^{18}$, Carolina Giraldo Alzate $\mathrm{MD}^{19}$, Jorge Rojas MD ${ }^{20}$, Juan Carlos Salazar-Uribe $\mathrm{PhD}^{21}$ Juan-Manuel Anaya $\mathrm{MD} \mathrm{PhD}^{22}$. Jaime Fernández-Sarmiento MD PhD $(c)^{1,23}$

${ }^{1}$ Department of Pediatrics and Intensive Care. Fundación Cardioinfantil-Instituto de Cardiología, Universidad de la Sabana. Bogotá, Colombia.

${ }^{2}$ Department of Pediatrics and Intensive Care. Clínica CardioVID. Medellín, Colombia.

${ }^{3}$ Department of Pediatrics. Hospital Pablo Tobón Uribe. Universidad de Antioquia, Medellín, Colombia.

${ }^{4}$ Department of Pediatrics and Intensive Care. Hospital Infantil Los Ángeles. Pasto, Colombia ${ }^{5}$ Department of Pediatrics and Intensive Care. Clínica Uros. Neiva, Colombia.

${ }^{6}$ Department of Pediatrics and Intensive Care, Hospital Universitario San Ignacio. Bogotá, Colombia. ${ }^{7}$ Department of Pediatrics and Intensive Care, Hospital General de Medellín. Universidad de Antioquia. Medellín, Colombia. Red Colaborativa Pediátrica de Latinoamérica (LARed Network).

${ }^{8}$ Department of Pediatrics and Intensive Care. Fundación Cardioinfantil-Instituto de Cardiología, Universidad del Rosario. Bogotá, Colombia.

${ }^{9}$ Department of Pediatrics and Intensive Care, Fundación Clínica Shaio. Universidad Nacional de Colombia. Bogotá, Colombia.

${ }^{10}$ Department of Pediatrics and Intensive Care, Hospital Susana Lopez de Valencia. Universidad del Cauca. Popayán, Colombia.

${ }^{11}$ Department of Pediatrics and Intensive Care, Hospital Militar Central, Hospital Santa Clara. Bogotá Colombia.

${ }^{12}$ Department of Pediatrics and Intensive Care, Clínica Infantil de Colsubsidio, Bogotá, Colombia.

${ }^{13}$ Department of Pediatrics and Intensive Care, Instituto Roosevelt. Bogotá, Colombia. 
${ }^{14}$ Department of Pediatrics and Intensive Care, Hospital Infantil de la Cruz Roja Rafael Henao Toro. Manizales, Colombia.

${ }^{15}$ Department of Pediatrics and Intensive Care, Fundación Santa Fe de Bogotá. Bogotá, Colombia.

${ }^{16}$ Department of Pediatrics and Intensive Care, Fundación Universitaria de Ciencias de la Salud. Hospital de San José. Bogotá, Colombia.

${ }^{17}$ Department of Pediatrics and Intensive Care, Clínica Portoazul. Puerto Colombia, Colombia.

${ }^{18}$ Department of Pediatrics and Infectious Diseases, Fundación Cardioinfantil-Instituto de Cardiología, Universidad del Rosario. Bogotá, Colombia.

${ }^{19}$ Department of Pediatrics and Intensive Care. Hospital Pablo Tobón Uribe. Medellín, Colombia.

${ }^{20}$ Department of Pediatrics and Intensive Care, Hospital Santa Clara. Bogotá Colombia.

${ }^{21}$ Research Group in Statistics, Universidad Nacional de Colombia, Medellín, Colombia.

${ }^{22}$ Center for Autoimmune Disease Research (CREA), School of Medicine and Health Sciences, Universidad del Rosario. Bogotá, Colombia.

${ }^{23}$ Universidad CES Graduate School. Medellín, Colombia.

Corresponding author: Jaime Fernández Sarmiento, MD. Universidad de La Sabana, Campus Universitario del Puente del Común, Km 7 Autopista Norte de Bogotá, Chía Cundinamarca - Colombia - Suramérica. JaimeFe@ unisabana.edu.co.+057-16672727 ext. 2204.

\begin{abstract}
Background

The clinical presentation and severity of Multisystem Inflammatory Syndrome in Children associated with COVID-19 is widespread and presents a very low mortality rate in highincome countries. This research describes the clinical characteristics of MIS-C in critically ill children in middle-income countries compared to described series in high-income countries along with the factors associated with mortality and worse outcomes.
\end{abstract}

\title{
Methods
}

An observational cohort study was conducted in 14 PICUs in Colombia between April 01, 2020 and January 31, 2021. Patient's age ranged between one month and 18 years and they met the requirements set forth by WHO for MIS-C.

\section{Results}

There were seventy-eight children in this study. The median age was seven years (IQR 111), 18\% (14/78) were under one year old, and 56\% were male. Thirty-five percent (29/78) 
were obese or overweight. The PICU stay was six days (IQR 4-7), and 100\% had a fever on admission lasting five days (IQR 3.7-6). Seventy percent (55/78) had diarrhea, and 87\% (68/78) had shock or myocardial dysfunction (78\%). Compared to the United Kingdom (UK) study, there were more children under the age of five (37\% vs. $10 \% ; \mathrm{p}=0.004)$, and there was a higher frequency of obesity $(29.5 \%$ vs. $10 \% ; \mathrm{p}=0.008)$. With regard to the US study, there was more lymphadenopathy ( $23 \%$ vs. $13 \%$; $\mathrm{p}=0.02)$, diarrhea $(70.5 \%$ vs. $53 \%$; $=0.001)$, lymphopenia ( $64 \%$ vs. $35 \%$; $\mathrm{p}=0.001)$, shock $(87 \%$ vs. $35 \% ; \mathrm{p}=0.001)$, elevated troponin (51\% vs. $31 \%$; $=0.006)$ and elevated proBNP ( $82 \%$ vs $43 \% ; \mathrm{p}=0.001)$, as well as greater mortality ( $9 \%$ vs $1.8 \%$; $=0.001$ ). The group that did not survive had a longer duration of the disease until admission to the PICU (6 days vs. 5 days; $\mathrm{p}=0.003$ ), more frequency of ferritin above $500 \mathrm{ngr} / \mathrm{mL}(100 \%$ vs. $45 \% ; \mathrm{p}=0.012)$ and more cardiovascular complications ( $100 \%$ vs. $54 \% ; p=0.019)$ compared to the group that survived.

\section{Conclusions}

Multisystem Inflammatory Syndrome in Children due to SARS-CoV-2 in critically ill children living in a middle-income country has some clinical, laboratory, and echocardiographic characteristics similar to those described in high-income countries. It was observed inflammatory response, and cardiovascular involvement were conditions that, added to the difficulties in accessing healthcare systems in countries with limited resources, may explain the higher mortality seen in these children.

Key Words: sepsis, SARS-CoV2, PIMS-TS, inflammatory, mortality.

\section{Background}

Since December 2019, when severe acute respiratory syndrome coronavirus 2 (SARS-CoV2) infection was described, high morbidity and mortality have been seen worldwide (1). This virus, which causes coronavirus 2019 disease (COVID-19), has been characterized by high transmissibility, severity, and lethality in adults $(2,3)$. However, most studies have described a less severe course in children. In general, 80-90\% of pediatric infections have an asymptomatic or mild infectious course $(3,4,5)$, and only $10 \%$ may require hospitalization and transfer to the pediatric intensive care unit (PICU) (4). However, by the end of April 2020, the UK and several European nations reported the appearance of a new presentation of SARS-CoV-2 infection, known as "Multisystem Inflammatory Syndrome in Children (MISC)," which behaves more aggressively, causing up to ten times greater mortality than that described for COVID-19 in the pediatric population $(6,7)$.

This clinical behavior is characterized by a severe hyperinflammatory state clinically similar to other diseases such as Kawasaki disease, toxic shock syndrome, and macrophage activation syndrome $(8,9)$. The pandemic began in China, spreading to Europe and North America and then to other world regions. Specifically, in May 2020, Latin America became the epicenter of the COVID-19 pandemic, an area already affected by social inequalities, with significant limitations in access to medical care, inadequate nutrition, and a high prevalence of many chronic non-communicable diseases (2).

The peak of MIS-C in most studies has been observed 4-6 weeks after the adult population's highest impact. With this MIS-C behavior around the globe, we expected to see the first cases 
in Latin America beginning in July 2020, and this was the case (11,12). Given the genetic, social, economic conditions and healthcare access in this region, this syndrome may exhibit different clinical behavior regarding severity, duration, and sequelae compared to what has been described in other parts of the world $(2,11,13)$. The objective of this study was to describe the characteristics, clinical course and mortality of MIS-C in a middle-income country and evaluate if there are differences in the affected groups and outcomes compared to what has been described in high-income countries.

\section{METHODS}

A multicenter observational study with retrospective and prospective components was carried out in 14 PICUs in Colombia from April 01, 2020, to January 31, 2021. All children from one month to 18 years of age who met the World Health Organization (WHO) criteria for MIS-C (Table 1) and were hospitalized in pediatric intensive care due to the severity of their condition were consecutively included. Also, to be included, they had to have had an RT-PCR, antibody, or antigen test within the first 48 hours of admission to intensive care showing current or recent SARS-CoV-2 infection. According to the described definition, patients with incomplete MIS-C criteria, or those with complete criteria for Kawasaki disease or toxic shock syndrome, were excluded. All the patients were followed up during their stay in intensive care. Clinical and echocardiographic variables, as well as lab exams and clinical progress, were also followed up.

This study was approved by the ethics committee at each participating institution, which was a requirement for including patients. The information was taken from the patients' charts and recorded in a database designed specifically for this study, to which only the principal investigators had access. All the data of interest to the researchers was recorded in the database, and patients with incomplete data were not included. Demographics, clinical characteristics, general acute phase reactants and those related to severity were recorded. The involvement of the different organs was assessed through clinical and paraclinical data. Likewise, the cardiovascular involvement was recorded by taking into account vasopressor support and the recording of echocardiograms performed, including measurement of the abnormalities found and the size of coronary aneurysms, using the Z-score. The presence of arrhythmias and troponin and proBNP disorders was noted, when available at the various time points, as well as patients who required cardiopulmonary resuscitation.

\section{Definitions}

The WHO definition of MIS-C was used, which includes age (0-19 years) and two of the following findings: a) rash or bilateral non-purulent conjunctivitis or mucocutaneous inflammation signs (oral, hands, feet); b) hypotension or shock; c) signs of myocardial dysfunction, pericarditis, valvulitis or coronary abnormalities (includes echocardiographic findings or elevated troponins/high proBNP); d) evidence of coagulopathy (elevated Ddimer, PT, PTT); e) acute gastrointestinal symptoms (diarrhea, vomiting, or abdominal pain) AND elevated inflammatory markers (ESR, CRP, or PCT) AND absence of other microbial causes of inflammation (bacterial sepsis, staphylococcal or streptococcal TSS) AND evidence of SARS-CoV-2 infection (RT-PCR, antigen test, positive serology) or contact with 
a COVID-19 patient. We defined coronary dilation as a Z-score between 2.0 and 2.4 and coronary aneurysm as a Z-score greater than 2.5. If the patient had more than one echocardiogram and follow up, all the data were recorded, assessing the tendency of the coronary dilations over time. Mechanical ventilation support and vasopressor requirement were recorded using the vasoactive score [dopamine $(\mathrm{mcg} / \mathrm{kg} / \mathrm{min})+$ dobutamine $(\mathrm{mcg} / \mathrm{kg} / \mathrm{min})+10 \mathrm{x}$ milrinone $(\mathrm{mcg} / \mathrm{kg} / \mathrm{min})+100 \mathrm{x}$ adrenaline $(\mathrm{mcg} / \mathrm{kg} / \mathrm{min})+100 \mathrm{x}$ noradrenaline $(\mathrm{mcg} / \mathrm{kg} / \mathrm{min})+10,000 \mathrm{x}$ vasopressin $(\mathrm{U} / \mathrm{kg} / \mathrm{min})]$, along with the treatments received in both dose and frequency. The acute kidney injury severity scale was recorded using KDIGO, as well as the need for renal replacement therapy due to acute kidney injury. Thrombocytopenia was defined as a platelet count less than 150,000, and lymphopenia was defined as a lymphocyte count less than 4,500 in children under eight months old and less than 1,500 in children over eight months old.

\section{Sample study}

The diagnosis of MIS-C according to the WHO criteria included a positive SARS-CoV-2 test such as the reverse transcription-polymerase chain reaction (RT-PCR) test, with samples taken from a nasopharyngeal swab or tracheal aspiration. Likewise, in cases where an IgM or IgG antibody test (immunodiffusion chromatography - Abbott) or serum antigen test was available, it was recorded

\section{Statistical analysis}

A descriptive analysis was performed using measures of central tendency according to the distribution of the variable, reporting means with their standard deviations or medians with interquartile ranges. Qualitative variables are reported in frequencies and percentages. A bivariate analysis was performed comparing the results of this study with results of MIS-C cases in the US reported by the CDC in Atlanta between April and October 2020 (11). Likewise, the results were compared with what was reported by Swann et al. regarding the behavior of MIS-C in the UK (10). These two reports in high-income countries were used, as the authors felt they were the most complete studies with the most representative data. Chi2 or Fisher's exact test were used for qualitative variables, and the Friedman test for repeated measures was employed for laboratory tests.

To estimate the odds ratios (ORs) and hazard ratios (HRs) of the factors at onset of symptoms that were substantially associated with mortality, we used both a logistic regression model for a dichotomous response and a proportional hazard Cox regression model.

In the first model, a logistic regression model was fitted making possible to estimate the effect size of significant variables on mortality which was coded as a dichotomous variable. The dependent variable of the logistic model was the natural log of the odds of survival. Specifically, the mathematical form of the logistic regression model was:

$$
\log \left(\frac{\pi}{1-\pi}\right)=\beta_{0}+\beta_{1} x_{1}+\beta_{2} x_{2}+\cdots+\beta_{k} x_{k}
$$

Where $\pi=P(Y=0 \mid X)$, the conditional probability of survival. The $\beta_{i}{ }^{\prime} s$ are regression coefficients, whereas the $x_{i} s$ represent clinical and statistical significant independent variables. The independent variables of the Cox model were selected through a backward selection procedure. To assess the clinical importance of significant variables, odds ratios (ORs) were computed. 95\% confidence intervals (CIs) for ORs and regression coefficients 
were also calculated. P-values $<0.05$ were considered significant. Statistical analyses were performed by using SAS PROC LOGISTIC implemented in SAS Studio.

In the second model, the Cox model, allowed us to estimate the effect size of significant variables at onset of symptoms associated with mortality. The dependent variable of the Cox model was the natural log of the risk of death at time t. Specifically, the mathematical form of the Cox model was

$$
\log (h(t))=\beta_{1} x_{1}+\beta_{2} x_{2}+\cdots+\beta_{k} x_{k}
$$

Again, the $\beta_{i} s$ are regression coefficients, whereas the $x_{i} s$ represent clinical and statistically significant independent variables. The independent variables of the Cox model were selected through a backward selection procedure. To assess the clinical importance of significant variables, hazard ratios (HRs) were computed. A hazard ratio measures the effect size of a variable on onset of symptoms to death. 95\% confidence intervals (CIs) for HRs and regression coefficients were also calculated. P-values $<0.05$ were considered significant. Statistical analyses were performed by using SAS PROC LIFEREG and SAS PROC PHREG implemented in SAS Studio.

\section{Results}

\section{Clinical characteristics of the patients}

During the study period from April 2020 to January 31, 2021, 155,207 cases of SARS-CoV2 infection in children were reported in Colombia, which corresponds to $7.4 \%$ of the adult infections. Of these patients, $0.1 \%$ were hospitalized in pediatric intensive care. Figure 1 shows the relationship between COVID-19 infections in children and MIS-C in critically ill patients under the age of 18 from April 2020 to January 2021.

\section{Figure 1. Temporal relation between COVID-19 infections and MIS-C in critically ill children under the age of 18.}

Cases of MIS-C included in this study and the report of SARS-CoV-2 infections in Colombia between April 2020 and January 2021.

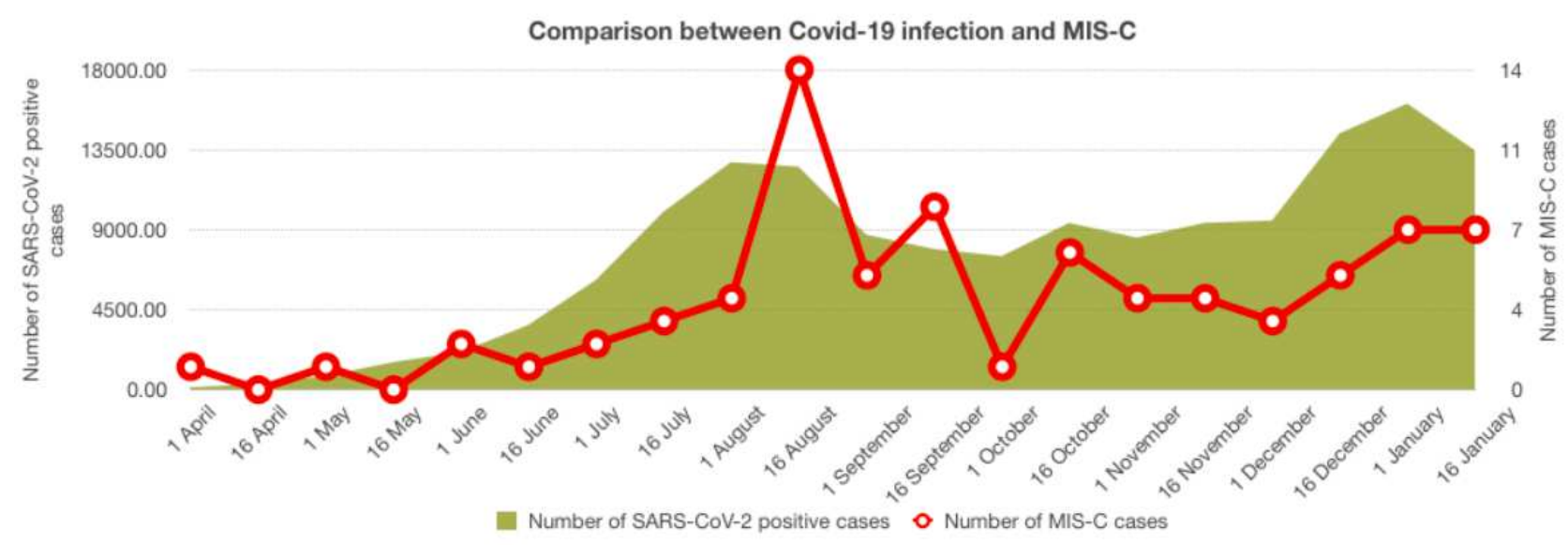

A total of 78 patients with MIS-C who were admitted to the 14 PICUs participating in this study were included. Fourteen patients $(18 \%)$ were under one year old. This age group 
showed no difference in the frequency of cardiovascular complications $(\mathrm{p}=0.96)$ or mortality $(\mathrm{p}=0.1)$ compared to older children. Overweight and obesity were found in 29 patients $(37 \%)$. With regard to symptoms, all the children had fever, with a duration of five or more days in $36 \%$ of cases, and more than 10 days in three patients (4\%). After fever, the most frequent symptoms were gastrointestinal (diarrhea, vomiting and abdominal pain) (Table 1). Sixtyeight patients were in shock $(87 \%)$ on admission, and 27 children $(36 \%)$ had pericardial effusion. The most frequent arrhythmias were sinus tachycardia in six patients, supraventricular tachycardia in three, ventricular tachycardia in one and ventricular extrasystoles in another.

Table 1. Demographic, clinical, laboratory and treatment characteristics of children included in the MISCO Study.

$\begin{array}{lc}\text { Demographic characteristics } & \mathbf{n}=\mathbf{7 8} \\ \text { Age in years, median (IQR) } & 7(1-11) \\ \text { Male sex, n (\%) } & 46(59) \\ \text { Origin according to altitude, n(\%) } & \\ \quad>1,500 \text { MASL } & 69(88.5) \\ \quad<1,500 \text { MASL } & 9(11.5) \\ \text { Nutritional status, n (\%) } & \\ \quad \text { Obesity } & \\ \quad \text { Overweight } & 23(29.5) \\ \quad \text { Undernutrition } & 6(7.7) \\ \text { Days in PICU, median (IQR) } & 45(57.7) \\ \text { Death, n (\%) } & 4(5.1) \\ \text { Days from onset of symptoms to admission to PICU (IQR) } & 6(4-7) \\ \quad \text { Survivors } & 7(9) \\ \quad \text { No survivors } & \\ \text { Clinical characteristics } & 5(1-92) \\ \text { Days from onset of symptoms and test, median (IQR) } & 6(3-12) \\ \text { Days of fever, median (IQR) } & \\ \text { Organ involvement } & \\ \text { Skin and mucous membranes, n (\%) } & \end{array}$


Gastrointestinal, n(\%)

Diarrhea

$55(70.5)$

Vomiting

Abdominal pain

$55(70.5)$

Neurological disorders, n (\%)

Headache

$17(22)$

Cardiovascular

Shock

$68(87)$

Hypotension

$61(78)$

Cardiac dysfunction $\overline{\mathbf{T}}$

14 (19)

Coronary artery dilation or aneurysms $\overline{\mathbf{T}}$

$19(25)$

Mitral regurgitationT

$16(21)$

Aortic regurgitation $\overline{\mathbf{T}}$

$2(1.3)$

Pericardial effusion $\bar{\top}$

$27(36)$

Arrhythmias

$11(14)$

Elevated troponin

$38 / 75(51)$

Elevated proBNP (> $400 \mathrm{pg} / \mathrm{m})$

$27 / 33(82)$

Renal, n (\%)

Acute kidney injury

$23(29)$

Respiratory

Lower $\mathrm{PaO} 2 / \mathrm{FiO} 2$, median (IQR)**

$152(98-260)$

Higher oxygenation index, median (IQR) ***

$14(8.7-25.5)$

Hematological, n(\%)

Elevated D-dimer > 3,000 ng/ml

$41(55)$

Anemia

$36(46)$

Thrombocytopenia ${ }^{\dagger}$

$28(36)$

Lymphopenia

$50(64)$

Elevated PTT

15 (19)

Elevated PT

8 (10)

Other, $\mathrm{n}(\%)$

Cervical lymphadenopathy $>1.5 \mathrm{~cm}$

$18(23)$

SARS COV-2 Labs, n (\%)

Positive PCR

$52(67)$

Positive antigen

$1(1)$

Negative PCR/Positive serology

$15(19)$

Positive serology

$10(13)$

Treatment

Immunoglobulin

$71(91 \%)$

Immunomodulator (eculizumab)

$1(1 \%)$

Steroids

$55(70.5 \%)$

Antivirals (Lopinavir)

$1(1 \%)$ 


$\begin{array}{lc}\text { Antiplatelet drugs } & 34(44 \%) \\ \text { Anticoagulants } & 34(44 \%) \\ \text { Vasoactive drugs, } \mathrm{n}(\%) & 59(76 \%) \\ \quad \text { Days of vasoactive drug use, median (IQR) } & 3(2-5) \\ \quad \text { Inotropic score, median (IQR) } & 21(10-35) \\ \text { Respiratory support II } & \\ \text { HFNC } & 24(31 \%) \\ \text { NIV } & 3(4 \%) \\ \text { Conventional MV } & 22(28 \%) \\ \text { HFOV } & 5(6.4 \%) \\ \text { Dialysis (RRT) } & 9(11.5 \%)\end{array}$

T In 75 patients who had an echocardiogram. ** Lower Pa02/Fi02 during PICU stay. ***Higher oxygenation index (OI) during PICU stay. PT - prothrombin time. PTT - partial thromboplastin time. HFNC - high-flow nasal cannula. NIV - noninvasive ventilation. MV - mechanical ventilation. HFOV - high-frequency oscillatory ventilation. RRT - renal replacement therapy. MASL --meters above sea level. II A single patient may have had more than one of the described respiratory supports during his/her PICU stay.

\section{SARS-CoV-2 test results}

The diagnosis was made via SARS-CoV-2 RT-PCR in 53 (68\%) patients, an antibody test in $24(30.1 \%)$, and by antigens in one (Table 1$)$.

\section{Inflammatory markers}

On admission, 62 patients (79\%) had a CRP greater than $3 \mathrm{mg} / \mathrm{dL}$, and of those whose ESR was measured, $50 / 63(64 \%)$ were over $40 \mathrm{~mm} / \mathrm{h}$. On admission, the lowest D-dimer value was 310 and the highest was $20,000 \mathrm{ng} / \mathrm{ml}$. Ferritin was over 500 in 39 patients (50\%). Additional file 1 shows the behavior of the inflammatory markers and other labs on admission and, in some cases, at 24 and 48 hours of follow up.

\section{Other labs}

Lymphopenia was seen in 50 patients (64\%). All those under one year old had an albumin level less than $2.5 \mathrm{~g} / \mathrm{dL}$, and all but one of those over this age had values less than $3.5 \mathrm{~g} / \mathrm{dL}$. Elevated total bilirubin for age was found in 25/54 patients (46\%) (additional file 1).

\section{Echocardiogram results}

An echocardiogram was performed on 75 patients (96\%) and, in these, the median left ventricular ejection fraction was 65\% (IQR: 57-70), and the median fractional shortening was 37\% (IQR: 29-40). Coronary anomalies were found in 35 patients (47\%); 27 patients (36\%) with a Z-score greater than 2.5 . Fourteen only had left coronary involvement, six had right coronary involvement, and six had anterior descending artery involvement. Ten patients had two affected coronary arteries, 16 had coronary artery hyperrefringence, four had ectasia, and seven had hyperrefringence and ectasia. 


\section{Treatment received}

Most of the patients did not receive antiviral treatment (98.7\%). Steroids were given to 55 patients $(70.5 \%), 42(54 \%)$ of whom received three to five-day methylprednisolone bursts, and $19(24 \%)$ of whom received dexamethasone for three to ten days. Seventy-one patients (91\%) received immunoglobulin treatment. Inotropic support was required for $76 \%$ of the patients, with a vasoactive score ranging from 4 in the best case to 345 in the worst case. Of the 11 patients who received invasive mechanical ventilation, five $(6 \%)$ required highfrequency oscillatory ventilation, including four of the five patients who died. Six patients (8\%) required MV for more than 10 days.

\section{Outcomes}

\section{Mortality}

There was a $9 \%$ mortality rate (7/78) in our study (Table 2$)$. The group that did not survive had a longer duration of the disease prior to being admitted to the PICU ( 6 days vs 5 days; $\mathrm{p}$ $=0.003)$, more frequency of ferritin above $500 \mathrm{ngr} / \mathrm{mL}(100 \%$ vs $45 \% ; \mathrm{p}=0.012)$, more cardiovascular complications $(100 \%$ vs $54 \% ; \mathrm{p}=0.019)$, more need for mechanical ventilation support $(100 \%$ vs $21 \% ; \mathrm{p}=0.001)$, and more need for renal replacement therapy ( $86 \%$ vs $4.2 \%$; $<$ <.001) compared to the group that survived (Table 2 ). Additionally, the group that did not survive had less diarrhea (14.3\% vs $76.1 \%$; OR $0.0495 \%$ CI 0.001 , $0.27 ; \mathrm{p}=0.01)$ and normal nutritional status $(100 \%$ vs $53.5 \% ; \mathrm{p}=0.018)$. $)$. In this way, the arrhythmias (HR $0.0395 \% \mathrm{CI} 0.002,0.40 ; \mathrm{p}=0.008$ ) and pericarditis (HR $0.0395 \%$ IC 0.003 , $0.408 ; \mathrm{p}=0.07$ ) were important variables associated from the onset of symptoms to death (table 3-additional file 2).

Table 2. Demographic, clinical, laboratory characteristics of children survivors vs nosurvivors included in the MISCO Study

$\begin{array}{lccc}\text { Demographic characteristics } & \begin{array}{c}\text { Survivors } \\ \mathbf{n}=71\end{array} & \begin{array}{c}\text { No-survivors } \\ \mathbf{n}=7\end{array} & \text { p-value* } \\ \text { Age < 7 years, n (\%) } & 32(45.1) & 5(71.4) & 0.23 \\ \text { Age > 7 years, n (\%) } & 39(55) & 2(28.6) & \\ \begin{array}{l}\text { Nutritional status, n (\%) } \quad \\ \quad \text { Obesity }\end{array} \quad 21(31) & 2(28.5) & 0.25 \\ \quad \text { Normal } & 38(53.5) & 7(100) & 0.018 \\ \text { Days in PICU, median (IQR) } & 11(6-114) & 13(9-65) & 0.46 \\ \text { Days from onset of symptoms to admission to } & & & \\ \text { PICU (IQR) } & 5(1-92) & 6(3-12) & 0.003^{* *} \\ & & & \\ \text { Skin and mucous membranes, n (\%) } & 16(22.5) & 1(14.3) & 0.61 \\ \quad \text { Lips/tongue } & 32(45.1) & 2(28.5) & 0.46 \\ \quad \text { Hand/foot edema } & 23(32.4) & 0 & 0.09\end{array}$


Gastrointestinal, n(\%)

Diarrhea

$54(76.1)$

$54(76.1)$

1(14.3)

0.002

Vomiting

$51(72)$

4(57.1)

0.36

Abdominal pain

$4(57.1)$

0.42

Cardiovascular, $\mathrm{n}(\%)$

Shock

$61(86)$

$7(100)$

0.98

Hypotension

$55(77.5)$

6(85.7)

0.6

Arritmia

$8(11.2)$

3(42.9)

0.05

Coronary artery dilation or aneurysms

$\begin{array}{lll}0 & 2(28.6) & 0.007\end{array}$

Pericarditis

Renal, n (\%)

Acute kidney injury

17(24)

6(85.7)

$<0.001$

Ferritin > $500 \mathrm{mcgr} / \mathrm{dl}, \mathrm{n}(\%)$

$32(45)$

$7(100)$

0.012

C-reactive protein > $4 \mathrm{mgr} / \mathrm{dl}, \mathrm{n}(\%)$

$58(82)$

4(57)

0.14

Dimero D > 3000 ngr/ml, n(\%)

$39(55)$

$5(71)$

0.46

Respiratory support, n (\%)
NIV
Conventional MV
HFOV

Dialysis (RRT), $\mathrm{n}(\%)$
68(96)

$15(21.1)$

$1(1.4)$

$3(4.2)$
0

$7(100)$

1.0

$<0.001$

$4(57.1)$

$<0.001$

$6(85.7)$ $<0.001$

NIV - noninvasive ventilation. MV - mechanical ventilation. HFOV - high-frequency oscillatory ventilation. RRT - renal replacement therapy. * Fisher-exact test. **Mann-Whitney U test

Table 3. Factors associated with mortality (by a logistic regression model).

\begin{tabular}{|c|c|c|c|c|c|}
\hline & $\widehat{\boldsymbol{\beta}}^{\mathrm{a}}$ & $95 \%$ CI for $\beta$ & P-value ${ }^{b}$ & $\begin{array}{l}\text { Odds Ratio } \\
(\text { OR })^{\mathrm{c}}\end{array}$ & $95 \% \mathrm{CI}$ for $\mathrm{OR}$ \\
\hline Arrhythmia $(\mathrm{No})^{\mathrm{d}}$ & 1.79 & $(0.26,3.32)$ & 0.02 & 35.73 & $(1.67,764.66)$ \\
\hline Diarrhea $(\mathrm{No})^{\mathrm{e}}$ & -2.77 & $(-4.89,-0.65)$ & 0.01 & 0.004 & $(0.001,0.272)$ \\
\hline Ferritin $^{\mathrm{f}}$ & -0.003 & $(-0.005,-0.001)$ & 0.02 & 0.997 & $(0.994,0.999)$ \\
\hline
\end{tabular}

Regardless of age.

a. The numbers in this column are estimates of the coefficients using the logistic regression model for a dichotomous variable as response (in this case, Mortality which is coded as 0 if the patient survives, 0 otherwise).

b. Tests the null hypothesis that $\beta$ is equal to 0 vs. the hypothesis that $\beta$ is different from 0 .

c. The odds ratio and its CI are adjusted for Arrhythmia, Diarrhea, and Ferritin.

d. This dichotomous variable was defined as 1 if the patient had Arrhythmia, 0 otherwise.

e. This dichotomous variable was defined as 1 if the patient had Diarrhea, 0 otherwise.

f. A one-unit increase in ferritin levels decreases the log of odds of survival by -0.003 units. In other words, the higher the ferritin levels, the greater the risk of mortality. 


\section{Comparison with MIS-C in high-income countries}

Table 4 shows the comparison of clinical characteristics between the subjects in our study and those reported in the US study by Godfred-Cato et al. (11) between March and July 2020, and the UK study by Swann et al. (10) between January and July 2020. With regard to sex, there were no statistically significant differences between the three studies. Obesity was more frequent in our study $(29.5 \%$ vs $10 \%$; $=0.008)$ compared to the data reported in the UK. With regard to the US study, lymphadenopathy was more frequent in our population (23\% vs. $13 \%$; $\mathrm{p}=0.002)$, as were diarrhea $(70.5 \%$ vs. $53 \% ; \mathrm{p}=0.001)$, vomiting $(74 \%$ vs. $62 \%$; $\mathrm{p}=0.03$ ) and lymphopenia ( $64 \%$ vs. $35 \% ; \mathrm{p}=0.001)$. With regard to the treatment received, in our study there was more frequent use of IVIG (91\% vs. $81 \% ; \mathrm{p}=0.001)$, steroids $(70.5 \%$ vs. $63 \% ; \mathrm{p}=0.03)$ and vasopressor support $(76 \%$ vs. $42 \% ; \mathrm{p}=0.001)$. Likewise, mechanical ventilation was needed more often $(28 \%$ vs. $13 \% ; \mathrm{p}=0.001)$ and there was greater mortality (9\% vs. $1.8 \% ; \mathrm{p}=0.001)$. Figure 2,3 and Table 4.

Figure 2. Comparison of the cardiovascular involvement in MIS-C between Colombia (MISCO STUDY), the US and the UK.

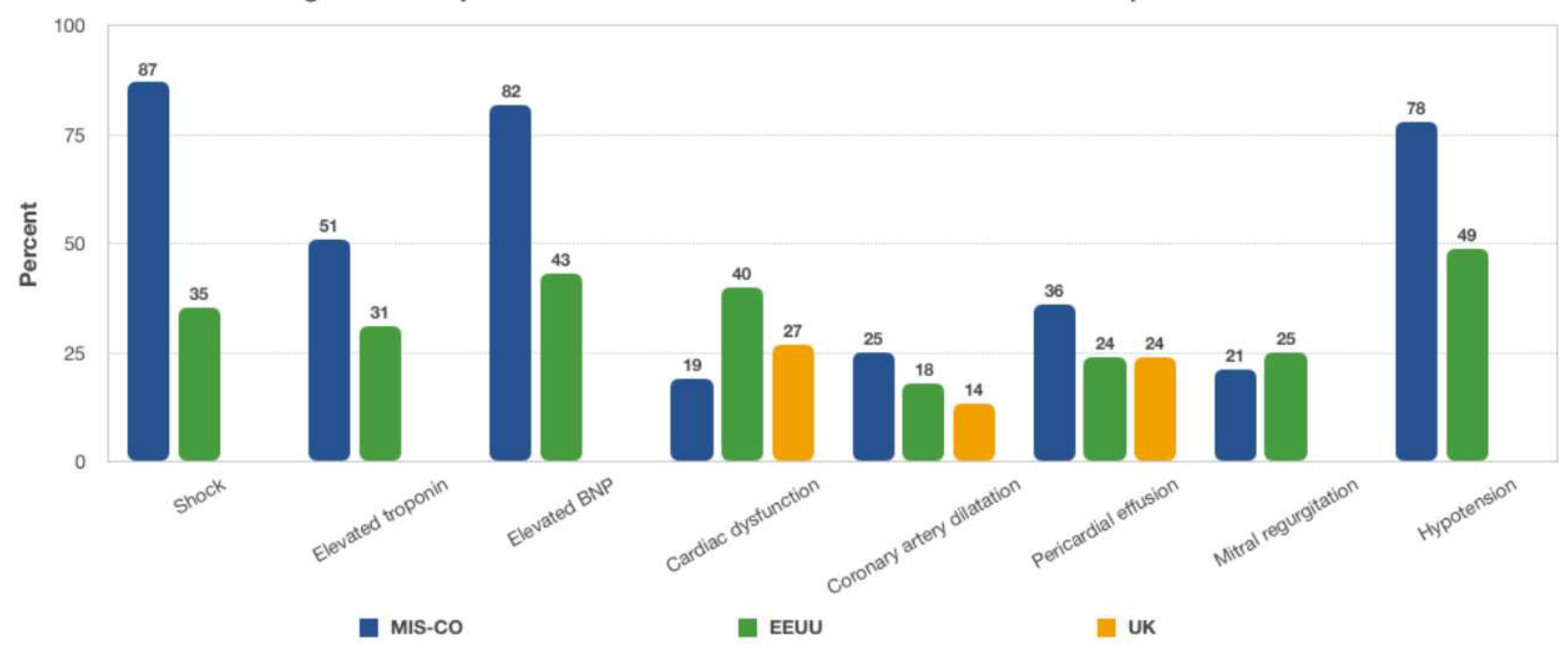


Figure 3. Comparison MISCO with other studies.

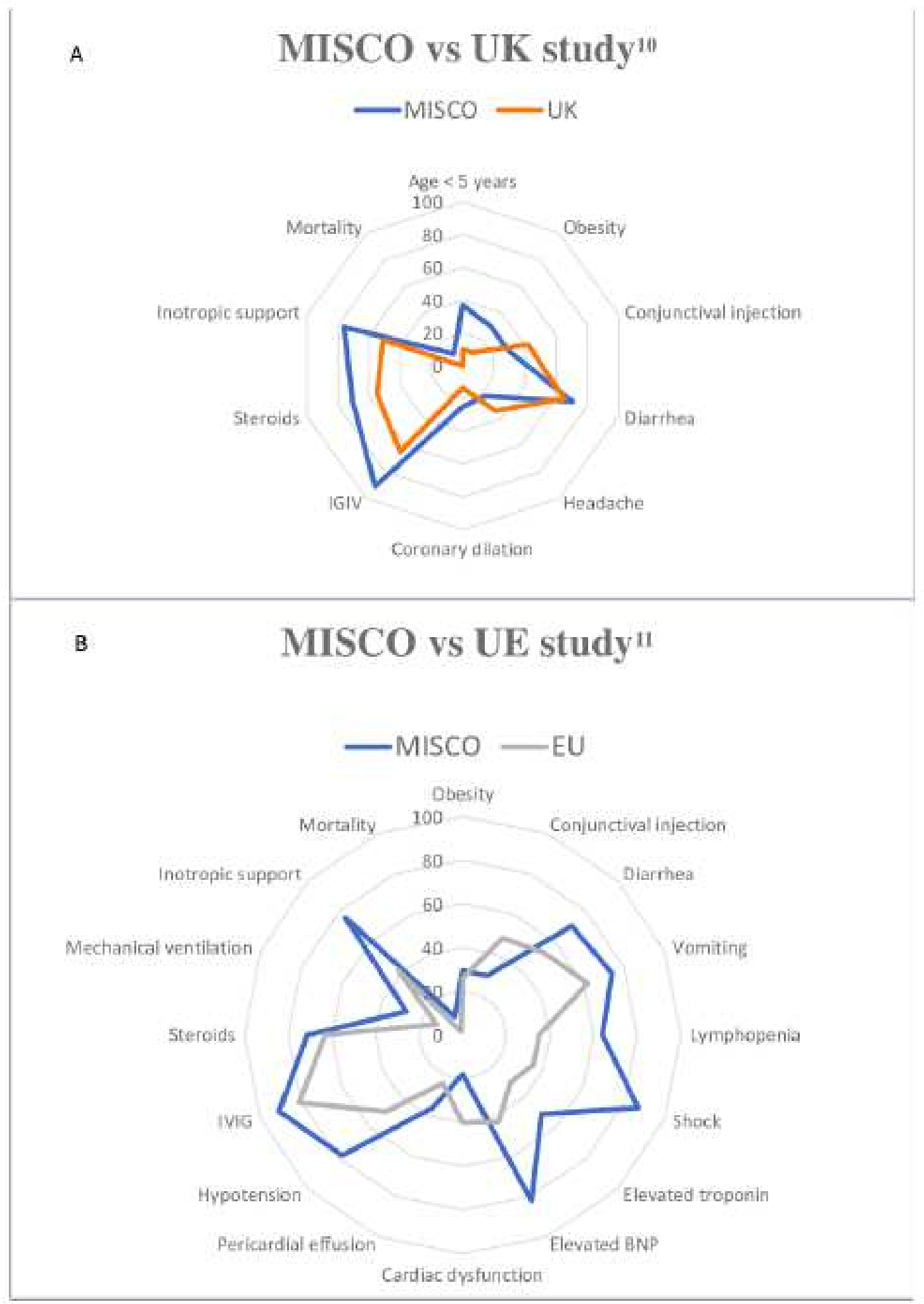


Table 4. Comparison of Colombian data with other studies

\begin{tabular}{|c|c|c|c|c|c|}
\hline & $\begin{array}{l}\text { MISCO } \\
\text { study } \\
\text { n }(\%)\end{array}$ & $\begin{array}{c}\text { MIS-C USA } \\
\text { n }(\%)\end{array}$ & P value ${ }^{a}$ & $\begin{array}{l}\text { MIS-C UK } \\
\text { n }(\%)\end{array}$ & P value $^{\mathrm{a}}$ \\
\hline Number of patients & 78 & 570 & & 52 & \\
\hline Patients in PICU & $78(100)$ & $364(63.9)$ & & $38(73)$ & \\
\hline $\begin{array}{l}\text { Age in years (median, } \\
\text { IQR) }\end{array}$ & $7(1-11)$ & $8(4-12)$ & & $\begin{array}{l}4.6 \quad(0.3 \quad- \\
13.7)\end{array}$ & \\
\hline $\begin{array}{l}\text { Age } \\
<5 \text { years } \\
\geq 5 \text { years }\end{array}$ & $\begin{array}{l}29 / 78(37) \\
49 / 78(63)\end{array}$ & $\mathrm{N} / \mathrm{R}$ & & $\begin{array}{l}5 / 52(10) \\
47 / 52(90)\end{array}$ & 0.004 \\
\hline $\begin{array}{l}\text { Sex } \\
\text { Male } \\
\text { Female }\end{array}$ & $\begin{array}{l}46 / 78(59) \\
32 / 78(41)\end{array}$ & $\begin{array}{l}316 / 570(55) \\
254 / 570(45)\end{array}$ & 0.55 & $\begin{array}{l}31 / 52(60) \\
21 / 52(40)\end{array}$ & 0.94 \\
\hline Obesity & $23 / 78(29.5)$ & $146 / 570(26)$ & 0.46 & $5 / 51(10)$ & 0.008 \\
\hline $\begin{array}{l}\text { Symptoms of KD } \\
\text { Fever } \\
\text { Changes in the mouth and } \\
\text { mucous membranes }\end{array}$ & $\begin{array}{l}78 / 78(100) \\
17 / 78(22)\end{array}$ & $201 / 570(35)$ & $\begin{array}{l}\text { NA } \\
0.018\end{array}$ & $52 / 52(100)$ & NA \\
\hline $\begin{array}{l}\text { Lymphadenopathy } \\
\text { Conjunctival injection }\end{array}$ & $\begin{array}{l}18 / 78(23) \\
23 / 78(29.5)\end{array}$ & $\begin{array}{l}76 / 570(13) \\
276 / 570(48)\end{array}$ & $\begin{array}{l}0.02 \\
0.001\end{array}$ & $\begin{array}{l}9 / 46(19.5) \\
20 / 48(42)\end{array}$ & $\begin{array}{l}0.6 \\
0.16\end{array}$ \\
\hline $\begin{array}{l}\text { Other symptoms } \\
\text { Diarrhea } \\
\text { Abdominal pain } \\
\text { Nausea/vomiting } \\
\text { Headache }\end{array}$ & $\begin{array}{l}55 / 78(70.5) \\
55 / 78(70.5) \\
58 / 78(74) \\
17 / 78(22)\end{array}$ & $\begin{array}{l}303 / 570(53) \\
353 / 570(62) \\
352 / 570(62) \\
186 / 570(33)\end{array}$ & $\begin{array}{l}0.001 \\
0.14 \\
0.03 \\
0.052\end{array}$ & $\begin{array}{l}32 / 49(65) \\
34 / 50(68) \\
38 / 50(76) \\
16 / 47(34)\end{array}$ & $\begin{array}{l}0.53 \\
0.76 \\
0.83 \\
0.13\end{array}$ \\
\hline $\begin{array}{l}\text { Labs } \\
\text { Lymphopenia } \\
\text { Thrombocytopenia }\end{array}$ & $\begin{array}{l}50 / 78(64) \\
28 / 78(36)\end{array}$ & $\begin{array}{l}202 / 570(35) \\
176 / 570(31)\end{array}$ & $\begin{array}{l}0.001 \\
0.37\end{array}$ & $16 / 50(32)$ & 0.65 \\
\hline $\begin{array}{l}\text { Cardiac complications } \\
\text { Shock } \\
\text { Elevated troponin } \\
\text { Elevated BNP } \\
\text { Cardiac dysfunction } \\
\text { Coronary dilation } \\
\text { Pericardial effusion } \\
\text { Mitral regurgitation } \\
\text { Hypotension } \\
\text { IVIG }\end{array}$ & $\begin{array}{l}68 / 78(87 \%) \\
38 / 75(51 \%) \\
27 / 33(82 \%) \\
14 / 75(19) \\
19 / 75(25) \\
27 / 75(36) \\
16 / 75(21) \\
61 / 78(78) \\
71 / 78(91)\end{array}$ & $\begin{array}{l}202 / 570(35) \\
176 / 570(30.9) \\
246 / 570(43) \\
207 / 510(40.6) \\
95 / 510(18.6) \\
122 / 510(23.9) \\
130 / 510(25.5) \\
282 / 570(49.5) \\
424 / 570(81)\end{array}$ & $\begin{array}{l}0.001 \\
0.006 \\
0.001 \\
0.002 \\
0.17 \\
0.02 \\
0.43 \\
0.001 \\
0.001\end{array}$ & $\begin{array}{l}10 / 37(27) \\
5 / 37(13.5) \\
9 / 37(24) \\
28 / 43(65)\end{array}$ & $\begin{array}{l}0.31 \\
0.15 \\
0.21\end{array}$ \\
\hline Steroids & $55 / 78(70.5)$ & $331 / 570(63)$ & 0.03 & $24 / 44(55)$ & 0.07 \\
\hline Mechanical ventilation & $22 / 78(28)$ & $69 / 570(13)$ & 0.001 & $14 / 52(27)$ & 0.87 \\
\hline
\end{tabular}




$\begin{array}{llllll}\text { High-flow cannula } & 24 / 78(31) & & \text { NA } & 23 / 52(44) & 0.11 \\ \text { Inotropic support } & 59 / 78(76) & 221 / 570(42) & 0.001 & 25 / 49(51) & 0.004 \\ \text { Death } & 7 / 78(9) & 10 / 570(1.8) & 0.001 & 0 / 51 & \text { NA }\end{array}$

${ }^{\text {a }}$ Chi square test or Fisher's exact test, as applicable. KD: Kawasaki disease. N/R Not reported

\section{Discussion}

In this study, we described 78 children under the age of 18 living in a middle-income country, who met the criteria for MIS-C associated with SARS-CoV-2 and who, due to the severity of their clinical condition, needed to be transferred to the pediatric intensive care unit. We observed that the affected children were younger and had more obesity, cardiovascular and gastrointestinal symptoms at the time of presentation than those in studies published in the US (11) and UK (10). In addition, these patients required vasoactive support and mechanical ventilation more often and had greater mortality compared to high-income countries.

In our study, $67 \%$ had a positive RT-PCR for SARS-CoV-2 at diagnosis, which is a higher frequency when compared to what has been observed in other studies (11). Thirty-three percent of our patients had serological evidence of SARS-CoV-2 infection with a negative RT-PCR, similar to what has been described in high-income countries. Likewise, the behavior of MIS-C in terms of frequency and severity also occurred 4-6 weeks after the peak in adults, as has been described.

Feldstein et al. (12) reported that the typical population affected by MIS-C is that of schoolage children, as we saw in our study. However, $18 \%$ of our population was under one year old and met the WHO criteria for MIS-C. These younger patients did not have more cardiovascular complications or greater mortality than the older children and had a very similar clinical course.

Similarly, it has been reported that MIS-C may occur more frequently in obese patients. The studies report a frequency ranging from $10-25 \%$ of cases having overweight and obesity $(10,11,12)$. We found this comorbidity in $37 \%$ of our patients. In middle and low-income countries, malnutrition related to poverty and scarce resources is increasingly found. According to $\mathrm{WHO}, 11.8 \%$ of children who live in middle-income countries have some type of malnutrition. Of these, 9.8\% have overweight and obesity, which in 2016 accounted for approximately 41 million children worldwide $(16,17)$. Diets based on complex carbohydrates and few proteins, along with more sedentary habits, are some of the explanations found by WHO to explain this phenomenon in countries with limited resources (16). In children affected by MIS-C, obesity has been associated with-greater hyperinflammatory response and endothelial, adipocyte, and macrophage activation, which explains some biomarkers' elevation in this disease (18). Endothelial activation may lead to vasoconstriction, prothrombotic states and the release of anti-mitogenic mediators (19-25). The association between obesity and the severity of endothelial activation and dysfunction in critically ill children is widely studied, particularly the more significant oxidative stress and insulin resistance which may occur in these patients $(26,27)$. 
In this regard, SARS-CoV-2 has been considered by some to be a systemic endothelitis $(20,21)$. Consiglio et al. (18), in a study of healthy children, children with COVID-19 and controls with Kawasaki disease and MIS-C, analyzed immune system cells, cytokines, and antibodies, finding that the inflammatory response in MIS-C mediated by the cytokine storm may be similar to that in Kawasaki disease, but with a few differential factors. There were differences in the T cells' response-, IL-17A, and a few other biomarkers associated with arterial injury in MIS-C. In particular, they found antibodies directed against some structural endothelial glycoproteins, such as endoglin, which suggests that these autoantibodies could be a research focus to determine targeted treatment for children with MIS-C (18).

Furthermore, in our study, we found shock, elevated troponin and proBNP, and myocardial dysfunction more often than in high-income countries $(10,11)$. We believe that several factors may explain this situation. In addition to the inflammatory response and endothelial activation seen, it is possible that healthcare system factors, such as rapid access to care, may have contributed to the higher frequency of cardiovascular involvement. Moreover, the lack of recognition may have contributed to the progression of the disease, with more frequent hemodynamic involvement. However, the frequency of coronary dilation and other cardiac involvement was similar to what has been seen in other countries.

Interestingly, in our study, $29 \%$ of the critically ill children were found to have kidney involvement on admission. The study by Feldstein et al. (12) reported $17 \%$ of this involvement in SARS-CoV-2 infection. Although the pathophysiological mechanisms are unknown, we believe that in our study, delayed consultation, the lack of early recognition, the more significant inflammatory response, and frequent cardiovascular involvement, among others, may explain this greater frequency of kidney injury. Adults report $20 \%$ of kidney involvement in COVID-19, which may reach 50\% in ICU patients, with a frequent need for continuous renal replacement therapy $(28,29)$. In children with MIS-C, LiptonM et al. (28) described 26 patients with acute kidney injury (AKI). This group found that renal involvement was associated with a greater elevation of CRP, ferritin, and procalcitonin, with greater lymphopenia and left ventricular dysfunction. It is suggested that the risk factors for acute kidney injury in children with MIS-C are greater age, greater inflammatory involvement, and ventricular dysfunction $(28,30,31)$. In our study, we found high CRP and ferritin, indicative of a significant inflammatory response, along with frequent ventricular dysfunction, which might explain, in part, the frequency of AKI seen.

In our study, there was much higher mortality (9\% vs. 1\%) than that described in high-income countries (6-10). We believe that several factors may contribute to these worse outcomes. Limited access to healthcare services (2), PICU availability, delayed consultation, greater severity of the myocardial involvement, arrhythmia, and shock at the time of admission, along with lack of recognition of the disease, may have contributed to these worse outcomes. Other factors such as environment, lifestyle, and availability of resources for timely health care must be considered in children with MIS-C. In a recent multicenter case-control study, children from minority racial or ethnic backgrounds were disproportionately at risk for developing MIS-C (32). 
We consider that our study has several limitations. First, not all the pediatric intensive care units in the country were included, which may have led to an under-reporting of critical MIS$\mathrm{C}$ cases. However, the participating centers are considered referral centers for most nearby towns, which capture a significant proportion of the pediatric population in Colombia. In addition, children with MIS-C who were not transferred to intensive care were not included because our objective was to analyze the characteristics of critically ill children with MIS-C. This decision may lead to an information bias, as only data from the most severely ill children is available. Likewise, data on inflammatory biomarkers, among others, and the progression of all the children affected by COVID-19 nationwide, were not available to make up a comparison group with less severe disease. Although we know that MIS-C cases are increasingly described worldwide, we decided to make a comparison with data reported up to June 2020 in the US and the UK (with a smaller study). More data from more extensive studies in these countries might show smaller differences. Still, we consider that in countries with limited resources, the socioeconomic and environmental factors may contribute to the observed outcomes. Finally, during the study period, variants of SARS-CoV-2 had not been reported in the country. We believe it is important-to keep a close watch on the different viral variants in these patients' records-and whether they have a different effect in children in terms of severity.

\title{
Conclusions
}

Multisystem Inflammatory Syndrome in Children associated with SARS-CoV-2 in critically ill children living in a middle-income country has some clinical, laboratory, and echocardiographic characteristics, similar to those described in high-income countries. Inflammatory response and cardiovascular involvement were conditions that added to the difficulties in accessing the healthcare system in countries with limited resources, could explain the greater mortality seen in these children. Prospective studies are needed to compare the different strategies of early recognition, availability of resources and type of treatments used to better understand the differences found and the MIS-C outcomes in countries with limited resources compared to high-income countries.

\author{
Abbreviations \\ SARS-COV2 \\ PICU: pediatric intensive care unit \\ RT-PCR: real time - polymerase chain reaction \\ Pro-BNP: proB-natriuretic peptide \\ PCT: procalcitonin \\ CRP: $\mathrm{C}$-reactive protein \\ MV: mechanical ventilation \\ HFOV: high-frecuency oscillatory ventilation \\ AKI: acute kidney injury \\ HRs: hazard ratios \\ CIs: confidence intervals
}

MIS-C: multisystem inflammatory syndrome in children asocciated with COVID-19

PIMS-TS: paediatric Multisystem inflammatory syndrome - temporally associated with 


\section{Acknowledgements}

We would like to thank the medical, nursing, and respiratory therapy team of the Pediatric ICU for their kind cooperation, as well as the clinical laboratory of the Fundación Cardioinfantil-IC, Hospital Pablo Tobón Uribe, Hospital Infantil Los Ángeles, Clínica Uros, Hospital Universitario San Ignacio, Hospital General de Medellin, Fundación Clínica Shaio, Hospital Susana Lopez de Valencia, Hospital Militar Central, Hospital Santa Clara, Clínica Infantil de Colsubsidio, Instituto Roosevelt, Hospital Infantil de la Cruz Roja Rafael Henao Toro, Fundación Santa Fe de Bogotá, Hospital de San José. Bogotá, and Clínica Portoazul in Colombia, South America.

\section{Authors' contributions}

Drs. LA, BEP, and JFS conceived the idea for the manuscript. Drs. LA, BEP, JFS, LFN, LM, IJAG, SH, JCJ, HM, GP, EZ, LI, JPM, JLJG, BGD, CBH, HP, ROM, MA, CGZ, JR,JCS and JA included patients in the database and participated in the analysis. All the authors drafted the manuscript and contributed significantly to the article revision. All authors approved the final manuscript as submitted and agree to be accountable for all aspects of the work. None of the researchers have conflicts of interest to declare.

\section{Funding}

Our research was funded by researchers' resources. We did not have financing from any other company.

\section{Availability of data and materials}

Datasets used or analyzed during the current study are available from the corresponding author on reasonable request.

\section{Ethics approval and consent to participate}

The ethics committee of all participating institutions and the children's parents approved to participate in this study. The name of the ethics committees that approved of the participating institutions were: Ethics committee from Fundación Cardioinfantil-Instituto de Cardiología, Clínica CardioVID, Hospital Pablo Tobón Uribe, Hospital Infantil Los Ángeles, Clínica Uros Hospital Universitario San Ignacio, Hospital General, Fundación Clínica Shaio, Hospital Susana Lopez de Valencia, Hospital Santa Clara, Clínica Infantil de Colsubsidio, Instituto Roosevelt, Hospital Infantil de la Cruz Roja Rafael Henao Toro, Fundación Santa Fe de Bogotá. This study was done in accordance with the Helsinki declaration. The informed consent was signed by the parents or legal guardian in all the participants.

\section{Consent for publication}

Not applicable.

\section{Competing interests}

The authors declare that they have no competing interests. 


\section{Bibliography}

1. World Health Organization. Coronavirus disease 2019 (COVID-19): situation report. Available: http://www.who.int/docs/default-source/coronaviruse/situation-reports.2.

2. Panamerican Health Organization (PAHO). Core Indicators 2019: Health Trends in the Americas. Washington, $\quad$ D.C.; 2019. Available in : https://iris.paho.org/bitstream/handle/10665.2/51542/9789275121290_eng.

3. Weiss P, Murdoch DR: Comment Clinical course and mortality risk of severe COVID-19. Lancet 2020; 395: 1014-1015.

4. Cruz A, Zeichner S: COVID-19 in children: initial characterization of the pediatric disease. Pediatrics 2020; e20200834.

5. Xiaoxia Lu, Liqiong Z, Hui Du et al: SARS-CoV-2 Infection in children. $N$ Engl J Med 2020; 382: 1663-1665.

6. Whittaker E, Bamford A, Kenny $\mathrm{J}$ et al: Clinical characteristics of 58 children with a pediatric inflammatory multisystem syndrome temporally associated with SARS-CoV-2. JAMA 2020; 324: 259-69.

7. WHO. Multisystem inflammatory syndrome in children and adolescents with COVID 19 scientific brief. Available: https://www. who.int/publications-detail/multisysteminflammatory-syndrome-inchildren-and-adolescents-with-covid-19.

8. Kam KQ, Ong J , Lee JH, et al: Kawasaki disease in the COVID-19 era: a distinct clinical phenotype?. Lancet Child Adolesc Health 2020; 4: 642-643.

9. Ouldali N, Pouletty M, Mariani P, et al: Emergence of Kawasaki disease related to SARSCoV-2 infection in an epicentre of the French COVID-19 epidemic: a time-series analysis. The Lancet Child \& Adolescent Health 2020; 4: 662-668.

10. Swan O, Holden K, Turtle L, et al: Clinical characteristics of children and young people admitted to hospital with COVID-19 in United Kingdom: prospective multicentre observational cohort study. BMJ 2020; 370: m3249.

11. Godfred-C S, Bryant B, Leung J, et al: COVID-19-Associated Multisystem Inflammatory Syndrome in Children. Centers for Disease Control and Prevention. MMWR 2020; 69: 1074- 1080.

12. Feldstein L, Rose E, Horwitz S.M, et al: Multisystemic Inflammatory Syndrome in US Children and adolecents. N Engl J Med 2020; 383: 334-346. 
13. Nguyen A, David J, Maden S, et al: Human Leukocyte Antigen Susceptibility Map for Severe Acute Respiratory Syndrome Coronavirus 2. J virol 2020; 94: e00510-20.

14. Kaushik S, Aydin SI, Derespina KR et al: Multisystem inflammatory syndrome in children (MIS-C) associated with SARS-CoV-2 infection: a multi-institutional study from New York City. J Pediatr 2020; 224: 24-29.

15. Pouletty M, Borocco C, Ouldali N, et al: Paediatric multisystem inflammatory syndrome temporally associated with SARS-CoV-2 mimicking Kawasaki disease (Kawa-COVID-19): a multicentre cohort. Ann Rheum Dis 2020; 79: 1-8.

16. Barrera Dussán N, Ramos-Castañeda JA. Prevalencia de malnutrición en menores de 5 años. Comparación entre parámetros OMS y su adaptación a Colombia. Univ. Salud 2020; 22: 91-95.

17. World Health Organization. Malnutrición. Available: https://www.who.int/es/newsroom/fact-sheets/detail/malnutrition.

18. Consiglio CR, Cotugno N, Sardh F. et al: The immunology of multisystem inflammatory Syndrome in children with COVID-19. Cell 2020; 183: 968-981.

19. Pons S, Fodil S, Azoulay E. et al: The vascular endothelium: the cornerstone of organ dysfunction in severe SARS-CoV-2 infection. Critical Care 2020; 24: 353.

20. Varga Z, Flammer AJ, Steiger P, et al: Endothelial cell infection and endotheliitis in COVID-19. Lancet 2020; 395: 1417-1418.

21. Wilson D, Schefold J, Baldirà J, et al: Adrenomodullin in COVID-19 induce endotelitis. Critical Care 2020; 24: 411.

22. Tonial C, Costa C, Andrades G. et al: Prediction of poor outcomes for septic children according to ferritin levels in a middle-income setting. Pediatr Crit Care Med 2020; 21: e259-e266.

23. Kohn-Loncarica G, Fustiñana A, Díaz-Rubio F et al: Recomendaciones para el manejo inicial del síndrome inflamatorio multisistémico relacionado temporalmente con COVID-19, en niños y adolescentes. Arch Argent Pediatr 2020; 118: e514-e526.

24. Fernández-Sarmiento J, De Souza D, Jabornisky R, et al: Paediatric inflammatory multisystem syndrome temporally associated with COVID-19 (PIMS-TS): a narrative review and the viewpoint of the Latin American Society of Pediatric Intensive Care (SLACIP) Sepsis Committee. BMJ Paediatrics Open 2021; 5: e000894. 
25. Rosário C, Zandman-Goddard G, Meyron-Holtz EG, et al. The hyperferritinemic syndrome: macrophage activation syndrome, still's disease, septic shock and catastrophic antiphospholipid syndrome. BMC Med 2013;11:185.

26. Radman M, McGuire J, Zimmerman J: Childhood Obesity, Endothelial Cell Activation, And Critical Illness. Front Pediatr 2020; 8: 441.

27. Dallan C, Romano F, Siebert J, et al: Septic shock presentation in adolescents with COVID-19. Lancet Child Adolesc Health 2020; 7: e21-e23.

28. Lipton M, Mahajan M, Kavanagh C. et al: Acute Kidney Injury in COVID-19-associated Multisystem Inflammatory Syndrome in Children (MIS-C). Kidney360 2021; 2 as doi:10.34067/KID.0005372020.

29. Nadim M, Forni L, Mehta R. et al: COVID-19-associated acute kidney injury: consensus report of the 25th Acute Disease Quality Initiative (ADQI) Workgroup. Nature Reviews Nephrology 2020; 16: 747-764.

30. Belhadjer Z, Méot M, Bajolle F, et al: Acute heart failure in multisystem inflammatory syndrome in children (MIS-C) in the context of global SARS-CoV-2 pandemic. Circulation 2020; 142: 429-436.

31. Llinás-Caballero K, Rodriguez Y, Fernández-Sarmiento J et al: Kawasaki disease in Colombia: A systematic review and contrast with multisystem inflammatory syndrome in children associated with COVID-19. Rev Colomb Reumatol 2021 as https://doi.org/10.1016/j.rcreu.2020.11.004.

32. Javalkar K, Robson VK, Gaffney L, et al: Socioeconomic and racial/ethnic disparities in multisystem inflammatory syndrome. Pediatrics $2021 ; 147$ as doi: $10.1542 /$ peds.2020039933.

\section{Additional file 1. Lab results}

Additional file 2. Estimated survival curve, based on a Cox model. The absence of arrhythmia has an $\mathrm{HR}=0.031,95 \% \mathrm{CI}=0.002-0.408, \mathrm{p}=0.031$; indicating that patients with arrhythmia tend to die faster than patients without it. 


\section{Figures}

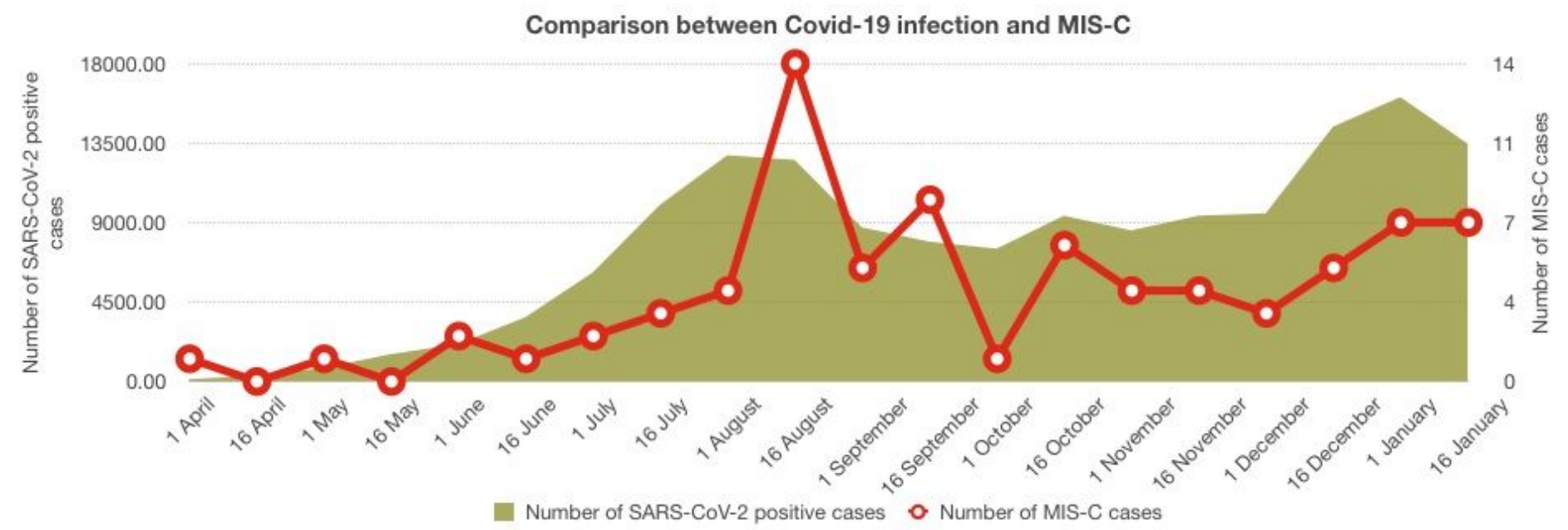

Figure 1

Temporal relation between COVID-19 infections and MIS-C in critically ill children under the age of 18 .

Cases of MIS-C included in this study and the report of SARS-CoV-2 infections in Colombia between April 2020 and January 2021.

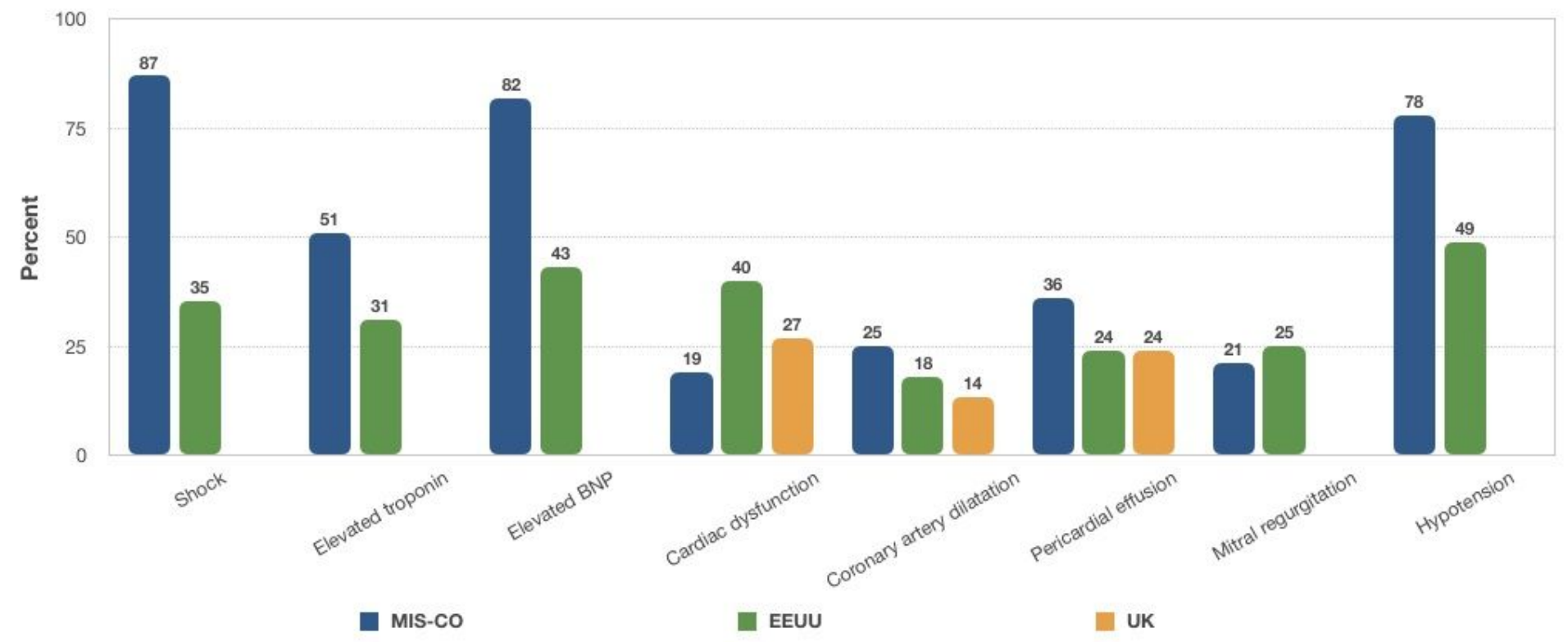

Figure 2

Comparison of the cardiovascular involvement in MIS-C between Colombia (MISCO STUDY), the US and the UK. 
A MISCO vs UK study ${ }^{10}$

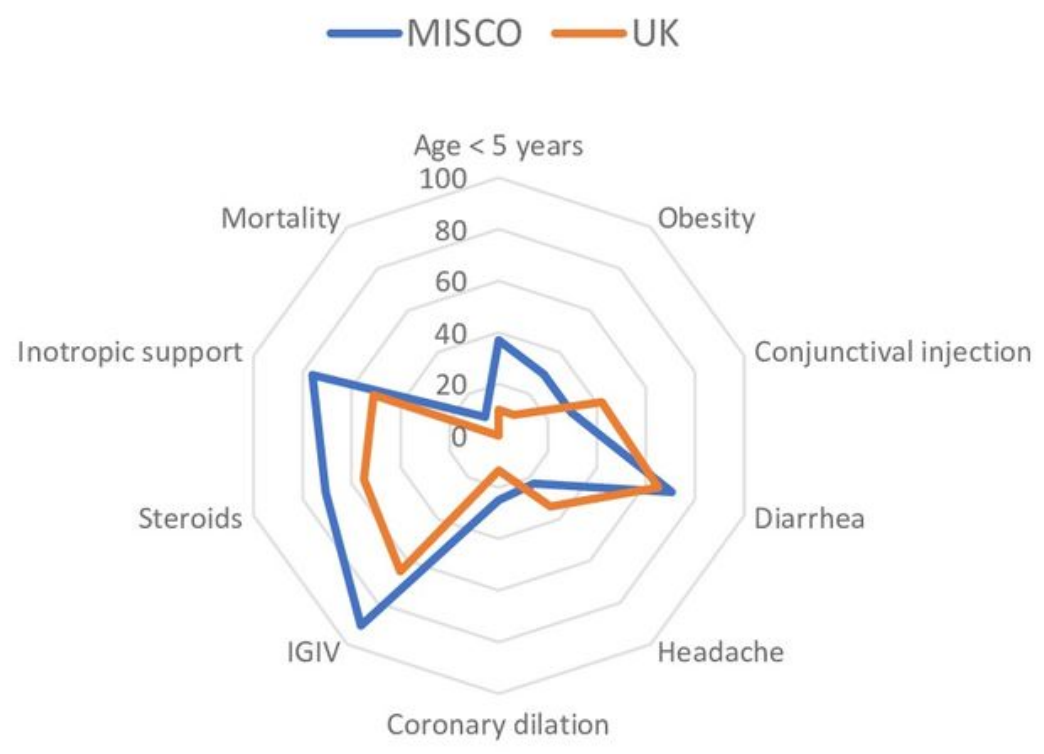

B

MISCO vs UE study"1

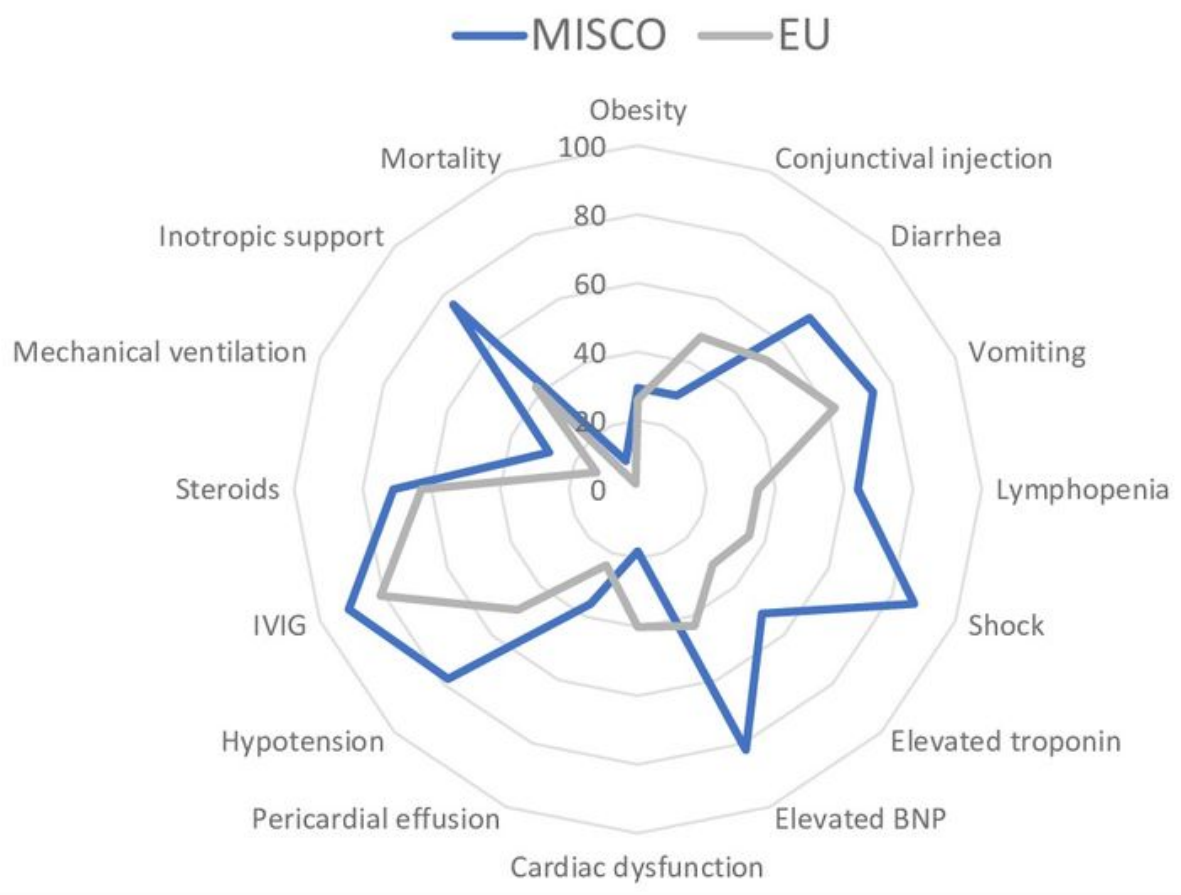

\section{Figure 3}

Comparison MISCO with other studies.

\section{Supplementary Files}

This is a list of supplementary files associated with this preprint. Click to download. 
- Additionalfile1.docx

- Additionalfile2Estimated.docx 